\title{
CENA E CENOGRAFIA NO ÍON DE EURÍPIDES
}

\author{
Adriane da Silva Duarte*
}

Universidade de São Paulo

\begin{abstract}
Resumo. Eurípides destaca-se entre os poetas trágicos pelo amplo emprego que faz de elementos visuais em sua poesia, valendo-se da écfrase. Em Ion dois momentos evidenciam essa qualidade, a descrição que o coro faz da fachada do templo de Apolo em Delfos, no párodo (184-221), e o relato do mensageiro, em que se narra o atentado à vida do herói homônimo (Íon, v. 1122-28). Concentrarei minha análise sobre esse última buscando demonstrar que Eurípides quis apresentar esta ação como se se tratasse de uma peça dentro da peça. O mensageiro emprega um vocabulário que remete aos termos técnicos do teatro e seu principal personagem, Íon, surge a uma só vez como ator, diretor e cenógrafo do drama que se desenrola longe dos olhos do público, mas ao alcance de seus ouvidos.
\end{abstract}

Palavras-chave. Écfrase; tragédia grega; Eurípides; Íon.

D.O.I. 10.11606/issn.2358-3150.v18i1p35-50

EURÍPIDES DESTACA-SE ENTRE os POETAS TRÁGICOS PELO AMPLO EMPREgo que faz de elementos visuais em sua poesia. ${ }^{1}$ Dentre suas tragédias, Íon é a que mais extensamente se vale desses recursos, a destacar a descrição parcial do templo de Apolo em Delfos no párodo (184-218), especialmente interessante por permitir imaginar a decoração de algumas de suas métopas, já que o edifício não resistiu ao tempo. No entanto, como não poderia deixar de ser, ele confere a esse recurso uma função dramática. Como aponta a helenista portuguesa Maria de Fátima Sousa e Silva em extenso ensaio sobre a relação do poeta com as artes visuais, Eurípides se vale dessas descrições para construir o espaço cênico, elegendo os elementos paisagísticos que "a tradição fornecia como identificativos de um determinado cenário do mito".2

\footnotetext{
* Professora adjunta de Língua e Literatura Grega da FFLCH/USP, pesquisadora do CNPq (nível 2) e líder do Grupo de Pesquisa Estudos sobre o teatro antigo.

** Artigo recebido em 05.ago.2015 e aceito para publicação em 31.out.2015.

${ }^{1}$ Shapiro $(1980,267)$ afirma ter sido ele o único tragediógrafo que se empenhou em levar a ékphrasis da épica para o drama.

2 Sousa e Silva 1985-1986, 10.
} 
Froma Zeitlin ${ }^{3}$ vai além ao notar que o teatro não se limita a refletir as conquistas arquitetônicas e das demais artes figurativas de seu tempo, mas "contribui efetivamente para seu desenvolvimento através dos avanços que faz no âmbito da perspectiva, coloração, percepção do próximo e do distante e na atenção conferida ao espaço pictórico, a começar com a decoração do cenário que se denomina skenographía (termo que mais tarde designará a perspectiva em geral)". Com isso, ela conclui, a influência entre as artes visuais e dramáticas é recíproca.

Aqui, no entanto, não interessará a representação material do espaço cênico, até porque são poucas as fontes para discuti-la, mas, sim, de que maneira o poeta constrói este espaço através de sua arte, ou seja, do discurso, induzindo o espectador a imaginá-lo.

A relação entre visão e da audição é intrínseca no teatro grego. $\mathrm{O}$ próprio termo que o denomina aponta para o elemento visual (théa, visão), no entanto, a acústica impecável dos edifícios gregos não deixa dúvida sobre a importância dada à compreensão do que é dito em cena. Embora visão e audição sejam complementares, a relação que mantêm é também dialética, pois dadas as convenções do drama antigo nem tudo é passível de ser mostrado diante dos olhos e, por outro lado, nem sempre há coincidência entre o que se vê e o que se escuta. Trata-se muitas vezes de um equilíbrio delicadamente construído entre os sentidos.

Aristófanes põe em cena, em As tesmoforiantes, um Eurípides às voltas com essa questão. No início da comédia, ele é visto na companhia de seu Parente andando apressado pelas ruas de Atenas. Diante da pergunta do Parente sobre aonde iam, o poeta responde (5-11):

EUR. Mas você não precisa ouvir tudo quanto em um instante verá com seus próprios olhos.

PAR. O quê? Repita!

Eu não preciso ouvir?

EUR. O que você vai ver, não.

PAR. Também não preciso ver?

EUR. O que você deverá ouvir, não.

PAR. Que conselho está me dando? No entanto, tem talento para falar. Não está falando que não preciso ouvir nem ver?

EUR. Difere a natureza de cada uma dessas ações. ${ }^{4}$

${ }^{4}$ Ar., Th. 5-11. Tradução de Adriane da Silva Duarte (Aristófanes 2005). 
Nessa passagem, oriunda do prólogo e, portanto, de viés programático, o poeta sugere que a redundância entre o ver e o ouvir constitui uma banalidade, devendo ser evitada. Melhor é quando um sentido supre a ausência do outro ou quando se atritam, emitem impressões divergentes. No teatro antigo há um momento em que essa exigência se cumpre totalmente. É quando entra em cena o mensageiro, testemunha única de uma ação que se desenrola fora de cena e, portanto, longe dos olhos dos espectadores. Irene De Jong ${ }^{5}$ mostra como este personagem goza de um estatuto especial, pois se apresenta como um espectador privilegiado que deve se valer da narrativa para fazer com que a plateia veja o que de seus olhos deliberadamente se ocultou. ${ }^{6}$ Se os diplomatas Persas, por sua atuação como informantes, mereciam o título de "o olho do Rei", o mensageiro trágico seria denominado com justiça "o olho do espectador", pois sua tarefa consiste em permitir que se visse com os ouvidos, se é possível colocar as coisas nestes termos. $^{7}$

Esse excurso se justifica pelo fato de este texto se ocupar de um relato de mensageiro. Comentarei a descrição que o mensageiro de Íon faz das tapeçarias que decoram a tenda em que o herói homônimo celebrará o início de uma nova etapa de sua vida (v. 1141-65). A junção de ékphrasis e de discurso de mensageiro é propícia, pois ambos têm como propósito tornar presente algo que não se apresenta à visão, empregando para isso apenas palavras. Vale notar que pouco interessa que o objeto descrito ou ação narrada, tenha existência real ou não. ${ }^{8}$ Importa que o poeta consiga criar uma imagem vívida dele através da sua arte, ou seja, dar-lhe corpo com palavras.

\footnotetext{
${ }^{5}$ De Jong 1991, 9-10.

${ }^{6}$ Os estudiosos consideram que os discursos de mensageiro se devem, ao menos em parte, a limitações de ordem técnica (a presença de um coro tornaria muito complexas as mudanças de cena, a limitação de atores a três imporia um número determinado de personagens, que poderiam multiplicar-se na narrativa), religiosa (milagres não podem ser mostrados em cena) e estética (convencionalmente mortes não são encenadas). Para uma discussão detalhada e indicação de bibliografia, cf. De Jong 1991, 117-8.

${ }^{7}$ O mensageiro de Suplicantes, de Eurípides, denomina-se theatés (E., Supp. 652). De Jong (1991, 183-4) apresenta uma relação das passagens em que verbos de visão aparecem nos relatos de mensageiros trágicos.

${ }^{8}$ No caso das ekphráseis do Íon, se é difícil falsear a descrição do templo do deus, bastante visitado pelos gregos, o poeta poderia escolher livremente o motivo dos tapetes que decoram a tenda que o herói constrói, já que esses objetos existiriam em grande número nos Tesouros do Santuário e dificilmente seriam individualizados. Até entre os relatos de mensageiro, em que pese a convenção do teatro grego que confere a eles total credibilidade, por vezes se encontra relatos enganosos. Em Electra (680-763), Sófocles atribui ao velho Preceptor de Orestes um longo discurso em que, apresentando-se como mensageiro, traz a Clitemnestra a falsa notícia da morte do filho durante uma corrida de carros nos jogos píticos. A mentira é tão elaborada que nos permite imaginar a cena à perfeição. Sobre esta passagem conferir Duarte 2010.
} 
Remeto às observações de Simon Goldhill ${ }^{9}$ sobre o papel crucial que a phantasía desempenha nesse processo.

Como Íon não está entre as tragédias mais conhecidas de Eurípides, creio que antes de passar à análise da passagem é importante retomar em linhas gerais o seu enredo. A ação acontece em Delfos, diante do templo de Apolo. Seu herói, Íon, é filho do deus, mas não sabe disso. De fato, ignora por completo sua origem. Hermes nos diz no prólogo que, fruto de uma relação ilícita com a princesa ateniense Creúsa, o bebê é abandonado à própria sorte e, resgatado posteriormente por ordens do pai, é transportado para Delfos, onde cresce ao abrigo do templo. Quando a peça tem início, Creúsa, que desposara Xuto, chega ao Santuário para consultar o oráculo sobre sua descendência. Eles não têm filhos, apesar de já estarem casados há muito tempo. Ela também pretende inquirir Apolo, sem que o marido o saiba, sobre o destino da criança exposta.

Apolo havia planejado dar Íon a Xuto, dizendo-lhe que era seu filho, para que, mais tarde, em Atenas, a mãe o reconhecesse e o tornasse herdeiro da casa real. O plano, que começa bem com Xuto aceitando a paternidade e convencendo o herói dela, esbarra na mágoa de Creúsa que, sentindo-se traída por ambos, por seu marido e pelo deus, e condenada a uma existência desprovida de descendência, decide vingar-se envenenando o rapaz em Delfos mesmo.

No entanto, graças à intervenção de Apolo, a trama da mãe é descoberta em tempo de evitar a morte, mas o problema se inverte. Agora é o rapaz que deseja matar a estrangeira que atentara contra a sua vida. Também o matricídio é evitado pela presença da Pítia que, portando os sinais de reconhecimento encontrados junto ao herói, promove o reencontro entre mãe e filho.

Por fim, Atena surge em cena ex-machina para revelar-lhes os desígnios de Apolo. Promete um futuro glorioso para Ílon e para Atenas e instrui-lhes a manter Xuto na ignorância, deixando-o acreditar ser o pai biológico do herói. Seguindo o conselho da deusa, mãe e filho celebram sua reunião.

A passagem que quero destacar situa-se no quarto episódio. O mensageiro, um servo de Creúsa, entra em cena em busca da rainha para transmitir ela e ao coro notícias urgentes e preocupantes. O plano de sua senhora para matar Íon fora descoberto resultando em sua condenação à morte. No

\footnotetext{
${ }^{9}$ Goldhill (2007, 5-6) parte de uma observação de Longino, em Do Sublime (15. 1), que vale a pena termos em mente: "Pois se o nome de aparição (phantasía) é comumente atribuído a toda espécie de pensamento que se apresenta, engendrando a palavra, agora o sentido que prevalece é esse: quando o que tu dizes sob efeito do entusiasmo e da paixão, tu crês vê-lo e tu o colocas sob

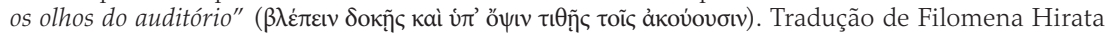
(Longino 1996).
} 
momento mesmo em que o relato é feito, Íon está a sua procura para cumprir a sentença. Apesar da gravidade da situação, o coro, composto pelas jovens acompanhantes atenienses de Creúsa, pede detalhes, argumentando que "se temos mesmo que morrer, será mais suave morrermos esclarecidas" $(1120-1) \cdot{ }^{10}$

O mensageiro atende seu pedido, expondo detalhadamente o que se passara longe da vista das moças, a começar da descrição do cenário montado para celebrar a uma só vez a reunião entre pai e filho, Xuto e Íon, e a despedida deste da Delfos onde havia sido criado (1122-32):

Assim que o marido de Creúsa saiu do templo, levando consigo o seu novo filho para o banquete e para os sacrifícios que tinha preparado para os deuses, dirigiu-se Xuto ao local onde salta o fogo báquico do deus, para alagar com o sangue das vítimas as duas rochas de Dioniso, em ação de graças por lhe ter sido concedido ver o filho. E disse:

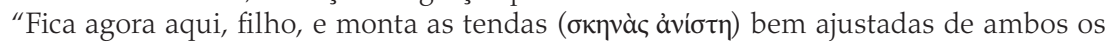
lados com o esforço dos construtores. Se eu me demorar muito tempo a sacrificar aos deuses do nascimento, que sirva comida aos teus presentes" E partiu levando consigo os novilhos.

A construção da tenda em si não devia causar estranheza, dado o afluxo de peregrinos necessitados de acomodação em Delfos, mas é igualmente evidente que sua menção, para os espectadores sentados no teatro, em Atenas, evocaria a skené erguida a cada ano para abrigar os espetáculos dramáticos. ${ }^{11}$ Afinal os espectadores estavam diante da estrutura em madeira, que servia a uma só vez como cenário e bastidor, cuja montagem teriam acompanhado poucos dias antes. Também contribui para essa associação o fato de Xuto ter escolhido, no Parnaso, as rochas dedicadas a Dioniso para celebrar seu sacrifício. Em Atenas, como se sabe, o principal festival dramático, a Grande Dionisia, acontecia no teatro vizinho ao templo de Dioniso Eleutério, e eram antecedidos por procissões e sacrifícios em honra ao deus. Sendo assim, a menção conjunta de sacrifício, Dioniso e skené, sugeriria aos espectadores que um novo drama estava em gestação.

Íon mesmo, como a sequência do relato evidencia, tal mestre carpinteiro, se encarrega da construção do edifício (1132-40):

Solenemente, o jovem estabeleceu com estacas os contornos desprovidos de muros das tendas, depois de ter observado bem os raios do sol, para que nem ficassem expostas ao brilho incandescente do meio dia, nem aos derradeiros raios do pôr do sol; e calculou a medida de um plectro para a regularidade dos ângulos, a qual detinha no meio a me-

\footnotetext{
${ }^{10}$ As citações do Íon seguem a tradução de Frederico Lourenço (Eurípides 1994). O texto grego segue a edição de David Kovacs para a Loeb Classical Library (Euripides 1999).

${ }^{11}$ Sobre as estruturas que abrigaram os espetáculos teatrais em Atenas durante o séc. 5 a.C. consultar Moretti 1999-2000, 396-8.
} 
dida numérica de dez mil pés, como determinam os peritos, de modo a poder chamar para o banquete todo o povo de Delfos.

Mais dois detalhes chamam aqui a atenção. A extensão da tenda projetada por Íon é de um plectro, ou seja, aproximadamente de trinta metros, o que corresponderia à largura da orquestra do teatro de Dioniso no ponto mais próximo da skené - segundo os arqueólogos, na época de Eurípides a orquestra ainda não era circular, mas tinha forma entre trapezoidal e retangular, valendo também lembrar que muitos não consideram que houvesse um palco elevado que separasse os atores dos coreutas, que evoluíam todos no mesmo espaço. Também é retangular o edifício projetado em Delfos, como era a skené do Teatro de Dioniso. Por fim, o edifício, com dez mil pés de área, era de tamanho extraordinário, concebido para acolher todo o povo de Delfos. Para o ateniense, a equivalência possível a isso seria o teatro, evento que congregava todos os cidadãos de Atenas num espaço único - especula-se inclusive que houvesse algum subsídio para garantir a presença aos espetáculos mesmo dos mais pobres.

A rapidez com que a tenda é erguida também não deve passar despercebida, uma vez que a ação dramática transcorre, como é praxe, no decorrer de um dia. Moretti ${ }^{12}$ considera que a skené do Teatro de Dioniso era construída com largas pranchas de madeira, que depois de desmontadas eram armazenadas na skenothéke. Sendo pré-fabricada, a depender do número de operários, a construção não deveria ser muito morosa, embora certamente não devesse se dar em um só dia. No entanto, penso que mais que um registro realista, Eurípides buscava simplesmente fornecer elementos que permitissem aos espectadores associar as edificações.

Uma vez concluída a obra, é chegado o momento de decorá-la. Para tal, Íon escolhe no Tesouro de Apolo várias tapeçarias (1141: ن́ $\varphi \dot{\alpha} \sigma \mu \alpha \tau \alpha)$, cobrindo com elas o teto, as laterais e a entrada da tenda. Parece-me que as tapeçarias fariam as vezes das paredes, de modo a permitir agilizar a construção e explicar porque o poeta dirá que Íon lançou mão delas para "dar sombra à tenda" (1141-2). A sua descrição, que se estende por vinte e três versos, constitui um dos mais notáveis exemplos de ékphrasis da poesia grega. Ei-la (1141-66):

Pegou em tapeçarias sagradas provenientes dos tesouros para dar sombra à tenda coisa maravilhosa de se ver. Primeiro lançou sobre os telhados as asas dos peplos, uma oferta do filho de Zeus - despojos das Amazonas que Héracles trouxera para o deus. Estas tapeçarias estavam tecidas com figuras: o Céu no círculo do éter reunindo os astros; o Sol guiando os seus cavalos para a chama derradeira do dia, arrastando o

${ }^{12}$ Moretti 1999-2000, 397.

Let. Cláss., São Paulo, v. 18, n.1, p.35-50, 2014 
brilho luminoso da Estrela da Tarde; a Noite vestida de negro conduzindo impetuosamente seu carro puxado por uma só parelha, e os astros seguindo no encalço da deusa; a Plêiade avançando no meio do éter e Órion segurando sua espada; lá no alto, a Ursa voltando para o pólo a sua cauda dourada; o círculo da lua cheia, divisora dos meses, atirando de cima seus raios; e as Híades, sinal claríssimo para os marinheiros, e a que traz a luz, a Aurora perseguidora dos astros. E pôs nas paredes outras tapeçarias dos bárbaros: naus, bem apetrechadas de remos, de fronte das helênicas; homens metade animais e cavaleiros caçando veados e selvagens leões. Junto à entrada, Cécrops perto das filhas enrolando e desenrolando as espirais, oferenda de algum ateniense - e colocou, no meio do refeitório, as taças douradas.

Construído e decorado sob a supervisão do herói, o pequeno edifício torna-se um palco dentro do palco e, de engenheiro, Íon torna-se cenógrafo e por fim ator do drama místico que vai se desenrolar neste cenário. Cabe estabelecer como a ékphrasis das tapeçarias ilumina a cena que se desenrolará nesse espaço cuidadosamente demarcado e elaborado. ${ }^{13}$

Em primeiro lugar, gostaria de marcar brevemente a adequação do discurso ao seu público imediato. Já foi observado anteriormente que o momento é de urgência. Tanto Creúsa quanto suas criadas, confidentes silentes e por isso cúmplices, estavam sendo procuradas para serem punidas. $\mathrm{O}$ mensageiro entra em cena afobado, imbuído da tarefa de informar o que se passa para que elas possam se salvar, mas quando começa a explicar-lhes o que dera errado com o plano de sua senhora, perde de súbito toda pressa, a ponto de descrever em detalhes as tapeçarias que enfeitam a cena do crime. Esse comportamento causa estranheza entre os comentadores da peça que o atribuem frequentemente a um arroubo virtuosístico do poeta. ${ }^{14}$ Mas seria esta o único motivo? Por que o mensageiro descreve com tanta minúcia a decoração da tenda?

Uma das razões está no caráter de seu público. As moças que compõem o coro desta tragédia demonstram desde o começo uma grande sensibilidade para a arte, pois tão logo entram em cena, no párodo, entregam-se à contemplação das métopas do templo de Apolo (184-221). Sem saber onde pousar os olhos, elas descrevem o que veem entalhado na pedra, condu-

${ }^{13}$ A tenda também se presta a uma série de interpretações simbólicas. Para além da ideia do palco, este espaço, interno, privado e escuro (o engenheiro previne cuidadosamente a entrada dos raios do sol), pode representar uma caverna, a em que o herói foi exposto, em Atenas, ou o recinto em que, em Delfos, a Pítia profetiza. A simbologia seria, então, evidente: a tenda é a uma só vez local de renascimento (caverna = útero, leitura reforçada pela presença dos tapetes, elemento eminentemente feminino e pelo sacrifício que Xuto faz "aos deuses do nascimento") e morte (caverna ateniense $=$ sepulcro), mas também de profecia, já que Íon interpreta os sinais divinos corretamente e escapa da morte. Sobre isso consultar Zeitlin 1996, 319.

${ }^{14}$ Sobre isso consultar dois artigos antigos, mas ainda muito influentes, sobre a tragédia em questão: trata-se de Pippin Burnett 1962, 96 e Wolff 1965, 180. 
zindo o olhar dos espectadores. ${ }^{15} \mathrm{O}$ poeta descreve não só o relevo do templo, mas também a reação maravilhada daquelas que o contemplam.

E o que elas veem? Estão representados nas "paredes de mármore"

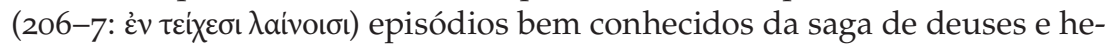
róis: Héracles e Iolau combatendo a Hidra de Lerna; a luta de Belerofonte contra a Quimera; a Gigantomaquia, com destaque para a participação de Atena, Zeus e Dioniso. As jovens os reconhecem e, especialmente no que respeita a Héracles, relacionam suas histórias aos "fios de seu tear" (196-7:

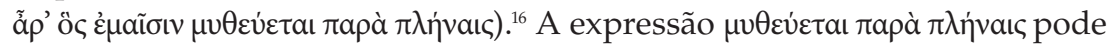
significar tanto "que foi contado [estando eu] ao lado dos fios de meu tear" ou "que foi contado pelos fios de meu tear". ${ }^{17}$ No primeiro caso a sugestão é que as mulheres entoassem canções sobre façanhas míticas enquanto trabalhavam como forma de regular o ritmo e de espantar o tédio; no segundo, que sua tapeçaria tematizasse esses episódios. De qualquer maneira, fica bem estabelecido o vínculo entre este coro e a tecelagem. Durante o primeiro estásimo, o coro volta a reafirmar essa ligação ao comentar sobre o destino dos filhos de deuses e mortais (507-8):

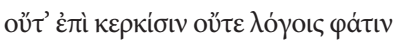

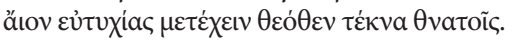

15 Naturalmente, esta passagem também constitui uma notável ékphrasis. Note-se a

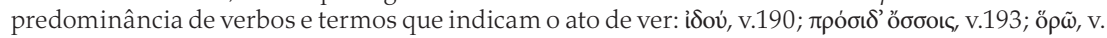

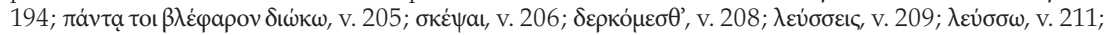
ó $\rho \tilde{\omega}$, v. 214. Discute-se em que medida essa ékphrasis se relacionaria com o cenário da tragédia, que se passa diante do templo do deus. Poderia haver uma pintura de cena que representasse o edifício, mas seria pouco provável que fosse tão detalhista a ponto de retratar as métopas descritas pelo coro. Mesmo que o fizesse, as figuras não seriam visíveis para os espectadores mais distantes... Como o frontão não foi preservado, não se sabe a acuidade com que Eurípides o descreveu, mas sendo Delfos um destino de peregrinação bem conhecido, é de supor que o poeta tenha tomado poucas liberdades com seu cenário - já descrever o templo de Ártemis na Taurida, hoje Crimeia, é outra história, pois, afinal, quantos dentre os espectadores teriam ido até lá? Apesar disso, o tragediógrafo se permitiu distorcer um pouco a paisagem délfica ao colocar em cena o altar do deus e a fachada oeste do templo, quando seria de se esperar a leste, em que figuraria Apolo. Assim, a ékphrasis teria como função apresentar aos espectadores a seleção de cenas entalhadas que interessava ao poeta destacar. Sobre isso consultar Müller 1975.

${ }^{16}$ Concordo com A. Tuck (2009) que o fato de as "histórias do tear" serem apontadas como fonte de reconhecimento da primeira imagem do templo induziria os espectadores a supor que o mesmo valeria para as demais cenas por elas comentadas. Isso seria certo no que se refere à Gigantomaquia, motivo tradicional do peplo que as atenienses ofertavam a deusa durante as Panatenáicas.

${ }^{17}$ Para o exame dessas citações, consultar Tuck (2009). Para ele, o coro se refere antes à prática ancestral de fazer acompanhar as tarefas com o canto. No entanto, ele também concede que estes cantos determinassem o padrão têxtil, ou seja, seu desenho. A relação entre canto e tecelagem é bem estabelecida na poesia grega e um dos exemplos mais notáveis dela está na Ilíada (3. 125-9), quando Helena é retratada por [Homero] tecendo um tapete que mostra o sofrimento de gregos e troianos por sua causa, mesmo tema do poema. Normalmente a passagem é interpretada como uma imagem para descrever a relação entre o aedo, o canto e o seu herói. Para uma investigação mais profunda da metáfora consultar Svenbro 2003. 
Nunca me chegou aos ouvidos qualquer relato de velhas histórias, nem mesmo sentada ao tear, em que os filhos de deuses e mortais tivessem uma existência feliz.

Esse comentário, que bem poderia se aplicar ao herói cujo feito fora gravado nas paredes do templo, Héracles, aqui é motivado pela história que Creúsa acabara de contar ao jovem Íon sobre o filho abandonado de Apolo, a sua história, muito embora ambos ignorassem isso. De qualquer maneira, importa notar novamente a associação entre o tecer e o contar histórias, o que torna este coro muito adequado para apreciar a descrição dos tapetes escolhidos por Íon para decorar sua tenda, cuja contemplação, promete o

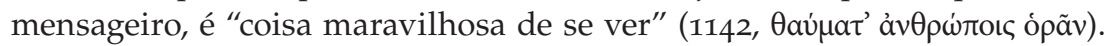
Os coreutas atuam então como uma plateia interna, cuja reação ao relato predispõe o público favoravelmente a ele.

Cabe notar que nosso herói também não é desprovido de apreço pelas artes. Numa conversa inicial com Creúsa, em que buscava se inteirar da genealogia da rainha, diz que contemplara em uma pintura a cena de Atena recolhendo Erictônio da terra e entregando-o aos cuidados das filhas de Cécrops (271: $\dot{\varepsilon} v$ үpạñ). Não deixa de ser curiosa a menção à imagem como reforço da palavra (prenúncio das tapeçarias descritas adiante?) nem a ideia subjacente de que a arte é fonte de conhecimento. Fica a sugestão de que não foi apenas o prazer do esteta que levou o mensageiro a se alongar na descrição dos tapetes da tenda, mas que eles devem ter algo a ensinar. Devemos, portanto, estar atentos à "voz da lançadeira".18

Depreende-se do relato que a tenda estava coberta de cima abaixo pelos tapetes, constituindo uma espécie de museu têxtil, a maneira dos quadros de David Teniers e Giovanni Pannini que retratam colecionadores de arte em meio aos seus acervos. ${ }^{19} \mathrm{E}$ as coleções, sabe-se, são uma tentativa de representar o mundo em sua totalidade. Dada a extensão da tenda, seriam necessariamente muitas as peças para recobri-la toda. No entanto, a exemplo do que ocorre na contemplação da fachada do templo, as tapeçarias serão agrupadas em três grupos temáticos, muito embora tratados de maneira desigual, cada qual distinto pela identificação de sua origem ou de seu doador ao templo, dado não menos importante para sua interpretação.

\footnotetext{
${ }^{18}$ A expressão consta de um fragmento do Tereu, de Sófocles, e é citada por Arist. Po. 1454b 36:

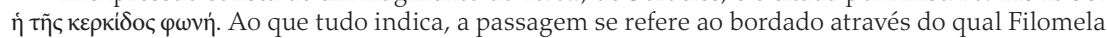
revela a sua irmã, Procne, a agressão de Tereu contra ela. Trata-se de um tecido que tem voz e, à maneira dos aedos, narra.

${ }^{19}$ Estou pensando nos quadros A coleção do arquiduque Leopold Wilhelm, de David Teniers (séc. 17), e em Galleria com vedute di Roma moderna, de Giovanni Pannini (séc. 18), localizados hoje respectivamente no Museu do Prado e no do Louvre, mas ao alcance dos internautas através de uma busca simples.
} 
Como parte do Tesouro do deus, elas testemunham o seu poder e a importância do Santuário não apenas entre os gregos, representados na oferenda de um anônimo ateniense, mas também entre bárbaros e heróis - Héracles está entre os doadores. Do alto para baixo, o mensageiro começará sua descrição pelo forro, um mapa celeste de espantoso detalhismo; nas paredes dispõem-se cenas de batalhas, de caçadas, de seres híbridos; na entrada, em destaque, a imagem de Cécrops e suas filhas. Como nota Zeitlin, "o conjunto apresenta uma mescla sinóptica que confirma o valor dos paradigmas míticos para interpretar e (influenciar) o presente".$^{20}$

Os peplos que encimam a tenda revelam um mapa celeste em que está representada, naquilo que um crítico chamou de "planetário têxtil" ${ }^{21}$, a passagem da noite para o dia. Não deve passar despercebido que esses tecidos pertenceram originalmente às Amazonas e que foram ofertados ao deus por Héracles. O herói já fora mencionado anteriormente na tragédia, estando parte de sua saga inscrita no frontão do templo - a luta contra a Hidra de Lerna. ${ }^{22}$ Então, pode-se supor que seu nome surge nessa passagem para (1) remeter ao frontão e associar as imagens, com ênfase em ambas no predomínio da ordem (cósmica e divina ou civilizadora com Héracles) sobre a desordem (monstros, amazonas), promovendo assim um complexo iconográfico através do diálogo entre as ekphráseis, em que uma ilumina a outra, (2) associar o destino de Héracles ao de Íon, já que ambos são fruto da união de deuses e mortais - como também são Belerofonte e Dioniso, destacados pelo coro nas métopas. Esse último aspecto prepararia a nova guinada na vida de Íon, que virá a descobrir que Apolo, e não Xuto, é seu pai. Igualmente apontaria para a presença de Atena para orientá-lo nesta etapa que se inicia, papel desempenhado junto a Héracles e Belerofonte. De forma complementar, a referência às Amazonas aponta para as circunstâncias que cercam seu nascimento, o abandono pela mãe e o recolhimento pelo pai, já que notoriamente as lendárias guerreiras só mantinham consigo as filhas mulheres, entregando os filhos aos cuidados paternos.

\footnotetext{
${ }^{20}$ Zeitlin 1996, 152.

${ }^{21}$ A expressão "a textile planetarium" foi cunhada por Shapiro $(1980,268)$.

${ }^{22}$ No peplo das Amazonas estão representadas as constelações de Órion, as Plêiades e as Híades (conglomerado de estrelas pertencentes à constelação de Touro), da Ursa Maior, demonstrando que os gregos já tinham formalizado um mapa do céu à altura em que Eurípides compõe sua tragédia. Curiosamente, traçando-se uma reta a partir da espada de Órion e da cauda da Ursa encontra-se a constelação da Hidra. Todas elas constam do catálogo que Ptolomeu estabelece em 2 d. C., baseado, por sua vez, nos escritos de Hiparco, de 4 a. C. Parece-me que essas escolhas não são aleatórias, mas ainda não sei como interpretá-las. No entanto, alguns classicistas dedicados à arqueoastronomia, especialmente Efrosyni Boutsikas, têm trabalhado a relação entre astronomia e religião na Grécia Antiga, especialmente no que respeita à orientação dos templos e o calendário dos festivais (cf. Boutsikas 2011a e 2011b).
} 
A imagem propriamente, tratada de forma mais extensa que as demais, ecoa outras passagens da tragédia, a começar do prólogo, quando Íon entra em cena e saúda o dia que nasce (82-85):

Ei-la, atrelada à luz, a quadriga resplandecente! O Sol já brilha sobre a terra e os astros fogem desta incandescência do éter para a noite sagrada!

No começo da peça, no entanto, o movimento dá-se na ordem contrária e o dia se impõe sobre a noite, expulsando astros noturnos. Já no estásimo que antecede a entrada do mensageiro, o coro evoca a dança do éter estrelado de Zeus, da lua e das Nereidas (1074-89), numa imagem que evoca o moto perpétuo. $\mathrm{O}$ "planetário celeste" retém essa ideia, retratando a movimentação incessante do cosmos, a passagem do tempo representada pela alternância entre noite e dia. Embora o céu noturno seja predominante, a menção marginal a Aurora, "filha da manhã", é prenúncio de um amanhã luminoso.

O episódio na tenda, vou me permitir chamá-lo assim, sinaliza para o futuro. Afinal, trata-se de uma festa de despedida não só de Delfos, mas de toda uma vida e por pouco não se torna o ato final de uma vida breve. É chegado o momento de o herói deixar para trás seu passado para abraçar um futuro inteiramente novo: um pai, que acabara de conhecer; uma cidade, na qual não sabe como será recebido; uma nova identidade, que se cristaliza no nome que acabara de receber - Íon, o errante, a partir do particípio do verbo eími, ir. Então, a descrição do céu noturno que aos poucos dá lugar à Aurora e ao raiar de um novo dia é bem adequada para o momento que Íon vive.

Além disso, da perspectiva humana, a imagem sugere a sucessão imutável dos dias o que remete à ideia de efemeridade, tão forte na poesia grega arcaica. O homem deve necessariamente viver um dia de cada vez, sabendo que nada é estável e que o amanhã é imprevisível. O destino do herói é um bom exemplo disso, uma vez que esse único dia em que se passa a ação dramática lhe reserva mudanças sucessivas e surpreendentes.

Por outro lado, a parada dos deuses, que no éter se encarregam de garantir inalterada a passagem do tempo, revela a ordem que prevalece no cosmos. Urano, Hélio, Noite e Aurora asseguram que tudo transcorrerá do modo devido - não se deve esquecer aqui Apolo, muitas vezes associado a Hélio como divindade solar. Mastronarde ${ }^{23}$, um dos primeiros a dar mais atenção a esta ékphrasis, toma esta imagem como reafirmação de ordem, permanência, serenidade, qualidades associadas aos deuses e contrapostas à

${ }^{23}$ Mastronarde 1975, 169.

Let. Cláss., São Paulo, v. 18, n.1, p.35-50, 2014 
desordem, instabilidade e violência, que marcam a vida dos homens, sobretudo dos descendentes da terra, como Creúsa e Íon, que atentarão contra as vidas um do outro.

Héracles, o doador das tapeçarias, é um símbolo ambíguo, pois representa a violência, por vezes fora de controle, mas também é o que a domestica, restaurando a ordem, ao combater seres monstruosos como a Hidra. O mesmo pode-se dizer de Íon, que descende de Apolo e de Erictônio, o que emergiu da terra, e que, portanto, compartilha de ambas as naturezas, celeste e terrestre.

Em seguida, o mensageiro conduz nosso olhar do alto para o baixo, as laterais da tenda, recobertas por tapetes provenientes de terras bárbaras (1159, $\beta \alpha \rho \beta \dot{\alpha} \rho \omega v$ v́ $\varphi \dot{\alpha} \sigma \mu \alpha \tau \alpha)$. Neles estão representadas batalhas navais, seres antropomorfos e cenas de caçadas. A menção às naus deve ser entendida como uma síntese das relações entre gregos e bárbaros desde Troia até as Guerras Médicas, aqui prefiguradas como o será, por Atena no êxodo, o futuro grandioso da cidade que acolherá o herói. Como assegura a deusa, em sua fala ex machina, os jônios, tribo da qual Íon dá nome, habitarão "as planícies dos dois continentes, as Ásia e da Europa" (1585-8), ampliando as fronteiras da Hélade, numa alusão clara às ondas colonizadoras. As imagens que se seguem talvez possam ser interpretadas nessa mesma luz como representações do encontro entre civilização e cultura, por um lado, e natureza e selvageria, por outro. Afinal, a presença de seres meio homens, meio bestas, por um lado, e de cavaleiros perseguindo corças e leões, por outro, sugerem essa mescla que, se não está restrita ao contraste entre ocidente e oriente, também alude a ela - os enfrentamentos entre heróis e monstros ou deuses e Gigantes, inscritos nas métopas, também se relacionam com estes motivos tecidos.

Por fim, no mesmo plano, mas em destaque, vê-se junto à entrada uma imagem de Cécrops e suas filhas, numa referência clara a Atenas, destino de Íon. A peça foi oferenda de um ateniense anônimo (1164-5: àAnvaíwv

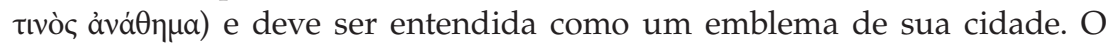
rei mítico de Atenas, representante maior da autoctonia de que tanto se orgulham seus cidadãos, é ele próprio um ser antropozoomórfico, já que a parte superior do corpo é de homem e a inferior é de serpente, como o mensageiro faz questão de ressaltar ("enrolando e desenrolando as espirais").

Para os gregos, as serpentes estão associadas à terra, e vários dos animais descritos nas imagens que perpassam a peça compartilham sua natureza: a hidra, a quimera, por sua cauda, além da Górgona e seus cabelos sibilinos, cuja efígie se imprime no bordado inacabado (outro trabalho de fio e trama) que Creúsa deposita junto ao recém nascido Íon e que permitiram mais tarde que viesse a ser reconhecido - além dele, um adorno de 
ouro em forma serpentina e um ramo sempre viçoso de oliveira completam o enxoval, ambos representando Atenas e a sua casa real. A serpente é, portanto, o elemento condutor desse complexo iconográfico que a tragédia tece. E, vale lembrar, é também um símbolo do poder de Apolo e de sua autoridade sobre Delfos, já que antes de instalar ali seu oráculo o deus teve que enfrentar e matar Píton, a serpente que lá habitava, outro ser oriundo da terra. Considerando que tanto a tapeçaria quanto as métopas que com ela dialogam pertencem ao deus e ao seu santuário, não é disparatado ver na associação dessas imagens um sentido religioso, voltado para afirmar a sua glória, cuidadosamente ressaltado pelo poeta. ${ }^{24}$

De fato, no drama que se desenrolará no interior da tenda-cena (skené), cujo toque final é a disposição das taças de ouro no meio do espaço, terá papel importante a gota fatal de sangue da Górgona, herança de Creúsa, que, segundo ela, "mata, como veneno que é das serpentes da Górgona" (v. 1015). Ou seja, as reiteradas alusões às serpentes chamam atenção para a natureza violenta e destrutiva dos filhos da terra, entre os quais se incluem Íon e a mãe, descendentes que são de Ericteu e Erictônio e que, ao menos no filho, deve ser neutralizada por influência do pai, o matador de Píton.

Por fim, deve-se observar que nessa peça em que os interesses de Apolo e Atena convergem em torno da figura de Íon, a deusa não poderia estar excluída do que se passa na tenda. O sangue da Górgona, emblema que figura no escudo da deusa, foi dado a Erictônio pela própria Atena e passado de uma geração a outra até que o recebesse Creúsa. Também nos tapetes pode-se ver a presença da deusa, que tem entre seus atributos a tecelagem, dom que partilha com as mortais. Assim, [Homero] anota que Atena, ao aprontar-se para a batalha, "deixa cair logo o peplo no soalho brilhante do Olimpo, obra de fino lavor que ela própria tecera e enfeitara". ${ }^{25}$ Também é obra de suas mãos as vestes que envergam Hera, para seduzir $Z_{\text {eus }}{ }^{26}$, e Pandora ${ }^{27}$, além de ter sido ela a instruir Penélope na arte de tecer ${ }^{28}$. Ovídio ${ }^{29}$ registra sua disputa com a infortunada Aracne, excelente tecelã que recusava prestar honras à deusa por seu dom e, por isso, acaba transformada em aranha, após uma disputa sobre quem tecia melhor. Pode-se supor assim que a deusa se faz presente por meio dos tapetes, produto de sua arte.

\footnotetext{
${ }^{24}$ Sobre isso consultar Müller 1975, 40.

${ }^{25}$ Hom., Il., 5.734-735. Tradução: Carlos Alberto Nunes.

${ }^{26}$ Hom., Il. 14.178-179.

${ }^{27}$ Hes., Op. 72; Th. 573.

${ }^{28}$ Hom., Od. 2.116-117.

${ }^{29}$ Ov., Met. 6.
} 
As tapeçarias, fruto da escolha do próprio Íon, revelam então sua identidade e seu destino e testemunharão o drama que ali se passará e que o mensageiro também se comprazerá em narrar. Concluída a construção da tenda, o arauto convida os délfios, o público, a entrar e festejar. Além de Íon, o velho criado de Creúsa desempenha papel proeminente na história. É ele, personagem cômico imiscuído na tragédia, que se oferece para servir os convidados, despertando o riso por sua diligência. É dele que Íon recebe a taça com a bebida envenenada.

Nesse momento, o que era para ser uma tragédia torna-se uma peça de mistério, a exemplo do gênero dramático que, na Idade Média, testemunhava a intervenção divina no mundo. Uma palavra de mau agouro inadvertidamente proferida por um dos servos, leva o jovem a dispensar a bebida e convidar os presentes a fazer o mesmo. Nisso, pombas adentram a tenda em revoada e se lançam sobre as poças de vinho. A que bebe onde Íon despejara o conteúdo de sua taça agoniza e morre diante dos olhos de todos. Imediatamente Íon acusa o velho de tentar matá-lo e ele confessa tudo.

O mensageiro descreve apenas aquilo que viu. Por isso não é taxativo sobre Apolo ter intervindo para salvar a vida de Íon. Mas tanto a palavra agourenta quanto a revoada das aves podem ser entendidas como sinais do deus que o herói soube muito bem interpretar - a tenda-cena está em Delfos, centro profético por excelência, vale lembrar. De fato, no êxodo, Atena revela que o deus, diante do risco que a mãe matasse o filho e vice-versa,

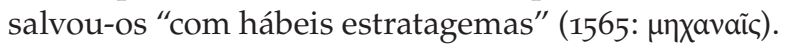

Assim, as tapeçarias, pertencentes ao tesouro de Apolo, que o mensageiro descreve com tanto vagar e deleite, dizem da natureza ambígua de Íon, de seu futuro, e, sobretudo, emolduram a intervenção milagrosa do deus nessa peça dentro da peça que Eurípides criou. Como nota Pippin Burnett ${ }^{30}$, “a descrição da tenda é frequentemente censurada devido seu caráter marcadamente não dramático, mas o fato dramático aqui é que uma espécie de epifania ocorreu, seu cenário deve ser celebrado com cuidado ritual".

Goldhill $^{31}$, em artigo recente, nota que muito se tem dedicado a explicar o que uma determinada descrição quer comunicar, qual o seu significado, enquanto que pouco esforço é feito para pensar sua função, ou seja, para que ela se presta. Wolff ${ }^{32}$ observa que, se muitas vezes ajuda a estabelece um cenário, a ékphrasis constitui um convite à contemplação, a examinar a situação por novos ângulos, promovendo o distanciamento necessário à

${ }^{30}$ Pippin Burnett 1962, 96.

${ }^{31}$ Goldhill 2007.

${ }^{32}$ Wolff 1965, 180: "[...] so descriptions and static pictures only furnish pauses in which the distance of seeing is interposed between the conflicts and action". 
reflexão. Esse modo contemplativo visaria a promover uma pausa no fluxo das ações. Voltando à relação entre tapeçaria e canto, que o coro estabelece e simboliza ao longo da tragédia, gostaria de sugerir, para concluir, que a ékphrasis da tenda ocupa na economia dramática da tragédia função equivalente a de um canto coral. Seus temas, suas imagens, tecidas no tear, poderiam muito bem ser cantadas ao seu pé ou no centro da orquestra do teatro de Dioniso. Não é também essa a função do canto coral?

\section{REFERENCIAS}

Aristófanes. 2005. Duas comédias: Lisístrata e As tesmoforiantes. Tradução, apresentação e notas de Adriane da Silva Duarte. São Paulo: Martins Fontes.

Boutsikas, Efrosyni. 2011a. "Temples, Stars, and Ritual Landscapes: The Potential for Archaeoastronomy in Ancient Greece." American Journal of Archaeology 115(1):55-68. DOI: 10.3764/aja.115.1.0055

Boutsikas, Efrosyni. 2011b. "Astronomical Evidence for the Timing of the Panathenaia." American Journal of Archaeology 115(2):303-9. DOI: 10.3764/aja.115.2.0303

De Jong, I. 1991. "Narrative in drama. The art of euripidean messenger-speech." Mnemosyne, supl. 116:9-10.

Duarte, A. S. 2010. "Um relato enganoso na Electra de Sófocles." In Estudos sobre o teatro antigo, organizado por Zélia A. Cardoso e Adriane S. Duarte, 25-38. São Paulo: Alameda.

Euripides. 1994. Íon. Tradução de Frederico Lourenço. Lisboa: Edições Colibri.

Euripides. 1999. Trojan Women, Iphigenia among the taurians, Ion, v. IV, edited by David Kovacs. Cambridge, Massachussets: Harvard University Press.

Goldhill, S. 2007. "What is ékphrasis for?" Classical Philology 102(1):1-19.

Longino. 1996. Do Sublime. Tradução de Filomena Hirata. São Paulo: Martins Fontes.

Mastronarde, D. 1975. "Iconography and imagery in Euripides' Ion." Classical Antiquity. 8:163-76.

Moretti, J.-Ch. 1999-2000. "The Theater of the Sanctuary of Dionysus Eleuthereus in Late Fifth-Century Athens." Illinois Classical Studies 24-25: 377-398.

Müller, G. 1975. "Beischreibung von Kunstwerken im Ion des Euripides." Hermes 103(1):25-44.

Pippin Burnett, A. 1962. "Human resistance and divine persuasion in Euripides' Ion." Classical Philology 57(2):89-103.

Shapiro, H. A. 1980. "Jason's cloak." Transactions of the American Philological Association $110: 263-86$.

Sousa e Silva, M. F. 1985-1986. “Elementos visuais e pictóricos na tragédia de Eurípides." Humanitas 37-38:9-86.

Svenbro, J. 2003. "Le manteau de Phèdre. Préhistoire du 'texte' em pays grecque." In Le métier de Zeus: mythe du tissage et du tissu dans le monde gréco-romain, edited by J. Scheid and J. Svenbro, 93-106. Paris: Editions Errance.

Tuck, A. 2009. "Textiles and the recitation of myth in Euripides." Arethusa 42(2):151-9. 
Wolff, C. 1965. "The design and myth in Euripides' Ion." Harvard Studies in Classical Philology 69:169-94.

Zeitlin, F. 1994. "The artful eye: vision, ecphrasis and spetacle in Euripidian theatre." In Art and Text in Ancient Greek Culture, edited by S. Goldhill and R. Osborne, 138-96. Cambridge: Cambridge University.

Zeitlin, F. 1996. "Mysteries of identity and designs of the self in Euripides' Ion." In Playing the other. Gender and society in classical greek literature, edited by F. Zeitlin, 285-338. Chicago: The University of Chigago Press.

\section{$*$}

Title. A play within the play in Euripides' Ion.

Abstract. Among the tragic poets, Euripides stands out by the wide use he makes of visual elements in his drama, especially the ekphrasis. Ion, in two moments, shows this quality: in the chorus' description of the temple of Apollo at Delphi façade (v.184-221), and in the messenger-speech ( $\mathrm{v}$.1122-1228). I will concentrate my analysis on the latter, in order to demonstrate how Euripides meant it as a play within the play. Not only does the messenger employ theatrical technical terms, but also the main character in the passage, Ion, arises once as an actor, director and scenographer of the drama that unfolds, distant from the audience eyes, but evidently able to reach their ears.

Keywords. Ecphrasis; Greek tragedy; Euripides; Ion. 